\title{
Informational and Analytical Support of Social and Labor Aspects of an Urban Settlement
}

\begin{abstract}
Submitted 06/02/19, 1st revision 26/03/19, 2nd revision 17/04/19, accepted 04/06/19
Polyakova I.A. ${ }^{1}$, Chernysheva Yu.G. ${ }^{2}$, Mikhailin D.A. ${ }^{3}$, Guzei V.A. ${ }^{4}$

Abstract:

Purpose: The aim of this article is to identify and assess the key problems of the city of Rostov-on-Don in social and labor aspects in order to determine the competitive position of the city relative to the million-plus cities regarding its advantages and key trends.

Structure/Methodology/Approach: To realize the goals of strategic planning, it seems appropriate: first, to obtain an analytical assessment of the state of the social and labor sphere of the city of Rostov-on-Don; second, to obtain a comparative assessment of the state relative to the cities of one million Russian citizens; third, to formulate the key problems that have arisen in this field and, fourth, to formulate the competitive position of the city of Rostov-on-Don.

Results: To arrange strategic directions for the development of the city of Rostov-on-Don, authors determined the competitive position of the city in the social and labor sphere in the form of advantages, key problems and key trends.

Practical implications: The results could be implemented at the municipality level in the formation of the spatial policy of urban development and improving the quality of life of the population.

Originality/Value: The main contribution of this study is to implement a system approach to the process of improving and developing information and analytical support for the management of municipal territories.
\end{abstract}

Keywords: Development of municipalities, assessment, strategy, indicators, digital economy.

JEL Codes: J10, J21, O18.

Paper Type: Research article in Special Issue dedicated to Russian Economy.

Section 7: Economic Development.

\footnotetext{
${ }^{1}$ D.Sc. in Economics, Professor, Department of Statistics, Econometrics and Risk Assessment, Rostov State University of Economics, Rostov-on-Don, e-mail:mirgan15@mail.ru ${ }^{2}$ D.Sc. in Economics, Professor of the Department of Analysis of Economic Activities and Forecasting, Rostov State University of Economics, e-mail: julia282001@mail.ru ${ }^{3}$ Ph.D. in Economics, Associate Professor, Department of Analysis of Economic Activities and Forecasting, Rostov State University of Economics, Rostov-on-Don.

${ }^{4}$ Ph.D. in Economics, Associate Professor, Department of Analysis of Economic Activities and Forecasting, Rostov State University of Economics, Rostov-on-Don.
} 


\section{Introduction}

Studies of various aspects of the social and labor sphere allow evaluating the effectiveness of social policy in terms of wages, supporting employment, organizing training and retraining of the workforce meeting the needs of modern social development.

The processes of informatization of society created the basis for the formation and implementation of a qualitatively new methodology for data accumulation, analysis, processing and making sound management decisions on this basis. The opportunities of organizing operational data collection, their long-term storage and structuring led to an information explosion called "Big data" and the transition to the "digitalization" phase of the economy. The most important direction of this process is the development of the economy of a new technological generation using a huge amount of data produced in various information systems. The organization of work with big data is based on the application of statistical methodology and applied methods, the dissemination of the experience of official statistics in data collection, the harmonization of definitions of indicators and the construction of their hierarchy.

On July 28, 2017, the Government of the Russian Federation approved the program "Digital Economy of the Russian Federation", the implementation of which is aimed at creating conditions for the development of the country's economy, in which "data in the digital form is a key factor of production in all areas of socio-economic activity, which increases the competitiveness of the country, the quality of citizens' life, providing economic growth and national sovereignty". The main emphasis of the document is put on the development of information technologies, which are modern tools for data transfer, accumulation and storage. Consequently, the sources of economic development are data and its analysis based on new technologies.

At the current moment, there is transformation of business management methods based on new principles of working with data, which requires mastering new competences for working with large amounts of information on the part of management and staff in all fields of activity. It is statistics as a field of scientific knowledge and practical activity that creates the basis for society to organize the entire logical sequence of working with information from collecting and accumulating its primary units to building and analyzing aggregated indicators, models reflecting the essence and patterns of functioning of various systems (Nivorozhkina, 2017).

State statistics has vast experience in collecting data, constructing aggregated indicators and analyzing multifaceted and multi-level processes occurring in all spheres of life. Accordingly, the strategic development of state statistics of Russia and its territorial structures at the present time is the further development of information resources for conducting research on the priority areas of social 
development of territories of various levels of localization, including their social and labor sphere (Polyakova, 2018).

Transformation processes in the economy of the Russian regions necessitate improving the efficiency of economic mechanisms and activating management structures to form the prerequisites for stable economic development and, as a result, to increase population's living standard. In turn, this necessitates balancing the resource capacity of the natural, economic and human potential of territorial systems, the high level of social and information infrastructure development, taking into account the transition to a digital platform and taking into account the needs of the population in the quality dimension of the living standard.

\section{Materials and Methods}

In the context of modern macroeconomic dynamics, the need to solve these problems makes relevant the research on the processes of reproduction of labor force in the context of the interdependence of labor and social relations, components of the socio-economic potential of the country and regions organically interconnected with all phases of the reproduction process (Yusov, 2009). Analytical review of the essence of the definition of "social and labor sphere" allows arguing that it is a system, its centre being an individual with personal needs, interests, motives and relations accompanying the work activity. The social and labor sphere is subject to the influence of global and local crises, which is reflected in the ratio of demand and supply of labor force, the unemployment and salary level, etc. The territory of residence and the individual's workplace is among the most significant factors characterizing the state of the social and labor sphere. This is a country as a whole, a region, a large city, any municipality, within which the social and labor sphere is exposed to both external problems and the influence of specific territorial factors. In this context, in-depth and comprehensive research requires the territorial aspects of the analysis and evaluation of processes occurring in all spheres of life.

The present study considers the contemporary state and development problems of the social and labor sphere in Rostov-on-Don, the largest city in southern Russia, the administrative centre of the Southern Federal District and Rostov region with the population of 1.130 .305 as of 1 January 2018 (Rostovstat, 2018). It is the tenth largest city in Russia. In total, over 2.16 million people live in the Rostov agglomeration (the fourth largest agglomeration of the country). The city is a major administrative, cultural, scientific, educational, industrial centre and the most important transportation hub in the south of Russia. In 2012, Rostov-on-Don took the 5th place in the quality ranking of the urban environment. In 2018, Rostov-onDon was one of the cities in Russia where matches for the World Cup were held.

The role of Rostov-on-Don as the capital of the Southern Federal District is predetermined by the accumulated demographic, production, consumer, infrastructural and cultural potential, favorable economic and geographical position. The importance of its location for the development of the social and territorial 
community has increased significantly in the context of integration and globalization and in the context of new geopolitical and geo-economic positioning of Russia. Taking into account the evolving realities, it seems reasonable to switch to a model of social development that implies the effective use of the city's strategic resources - human potential, economic and social potential, the territory itself and the modernization of the city management system. At the same time, it is necessary to support the development of not only the "city for business", but also the improvement of the "city for life", providing resource-saving economic development based on innovative types of economic activity.

Currently, Rostov-on-Don and other cities of over one million have developed strategies for socio-economic development for the period up to 2035. Strategic planning is the most important component of the city management system, which forms the institutional and socio-economic conditions for the sustainable development of an urban settlement based on the effective use of the resource and market potential to ensure a decent quality of life for the population. The development strategy represents general goals, directions, principles, tasks and methods of actions city management bodies take in the economic and social sphere in the long-term perspective. This document is comprehensive, based on in-depth and comprehensive analysis and assessment of all components of the urban environment, taking into account the interests of all business entities, the population of the city and determines the system of long-term goals, priorities of socioeconomic policy and mechanisms to achieve the planned goals.

This study examined the basic indicators of the state of the social and labor sphere in Rostov-on-Don as part of the implementation of an employment strategy. The purpose of this strategy is the efficient use of available resources to ensure decent work and social protection in payment issues and working conditions. The state of the labor market, employment and incomes of the population of the city in the context of the further development of the social and labor sphere is significant for the preservation, enhancement and rational use of the labor potential of an urban settlement and its integration into the system of international economic relations, within which a highly qualified mobile labor force is a decisive prerequisite for competitiveness provided with sustainable employment.

The empirical base of the study was the state statistics and the results of special surveys on employment and unemployment in the dynamics for 2013-2016. The key indicators reflecting the state of the social and labor sphere of the city presented in the municipal statistics of the Territorial Body of the Federal State Statistics Service for Rostov region (Rostovstat) and development forecasts for Rostov-on-Don and Rostov region are the following: the average number of employees; the number of the unemployed registered with the employment service; average monthly nominal accrued salaries. Analysis of the actual values of these indicators for 2013-2017 and their comparison with strategic values shows that in terms of the indicator "The average number of employees in the full circle of organizations", the results 
achieved by 2017 are lower than the target values of the indicators, which is caused by the crisis recession in the city economy.

According to the analysis, the dynamics of registered unemployment has a positive trend. The share of employed citizens exceeds the values of target indicators. Despite the crisis in the country's and city's economy, the values of the average monthly nominal accrued salaries exceeded the target values. Table 1 presents the dynamics of the average monthly salary for Rostov-on-Don, from which it follows that the period from 2013 to 2016 was characterized by a transition to a lower rate of growth of the population's living standard. It should be noted that the increase in salaries and social payments until 2016 was higher on average than the level of real incomes falling among the working population, that is, the process of reducing real incomes affected households with young children, pensioners and non-working citizens, whose incomes mostly depend on the amount of social payments.

Table 1. Dynamics of the average monthly salary in Rostov-on-Don (Developed by authors on the basis of Rostovstat, 2018)

\begin{tabular}{|l|l|l|l|l|l|}
\hline Indicator & 2013 & 2014 & 2015 & 2016 & 2017 \\
\hline $\begin{array}{l}\text { Average monthly salary of } \\
\text { employees at enterprises } \\
\text { and organizations (with } \\
\text { social payments), RUR }\end{array}$ & 26942.0 & 28920.4 & 30323.8 & 32209.4 & 32923.3 \\
\hline \% to the previous year & 113.6 & 107.3 & 104.9 & 106.2 & 102.2 \\
\hline $\begin{array}{l}\text { Average monthly accrued } \\
\text { salary per employee, RUR }\end{array}$ & 26688.4 & 28674.9 & 30069.3 & 31918.3 & 32209.4 \\
\hline \% to the previous year & 113.4 & 107.4 & 104.9 & 106.1 & 100.9 \\
\hline
\end{tabular}

Sectoral differentiation of salaries should be taken into account, in particular, there is no salary indexation referring to public sector employees' salaries and salaries of certain categories of employees working in municipal institutions of the public sector. In its turn, it negatively affected the living standard of this part of the population. The dynamics of the number of employees at enterprises and organizations of the city indirectly characterizes the success of its functioning as an integral business entity, which is reflected in Table 2.

Table 2. Dynamics of the average number of employees at the full range of organizations, Rostov-on-Don (Developed by authors on the basis of Rostovstat, 2018)

\begin{tabular}{|l|l|l|l|l|l|}
\hline Indicators & 2013 & 2014 & 2015 & 2016 & 2017 \\
\hline $\begin{array}{l}\text { Average number of employees at } \\
\text { the full range of organizations in } \\
\text { Rostov-on-Don, thous. employees }\end{array}$ & 428.7 & 421.4 & 412.5 & 406.1 & 426.4 \\
\hline $\begin{array}{l}\% \text { compared to the previous } \\
\text { period }\end{array}$ & 98.3 & 98.3 & 97.9 & 98.4 & 104.9 \\
\hline
\end{tabular}


The data in Table 2 reflects the dynamics characteristic of recent years towards the reduction in the number of employees: in 2013, there was a decrease by 12.9 thousand people, in 2014 - by 16.5 thousand people, in 2015 - by 9.2 thousand people, in 2016 - by 6.3 thousand people. However, 2017 (as of 1 November 2017) indicated the significant increase in the number of employees (20.3 thousand people), which correlates with the index of industrial production by medium and large enterprises, the value of which in 2017 amounted to $112.8 \%$. In addition to the above, the growth in the number of the employed in the city was influenced by the preparation to the World Cup.

Table 3 shows the dynamics of the registered unemployment rate. The value of this indicator remained relatively stable over the entire analyzed period of time. However, the values of the index of registered unemployment in the city as a whole for the period under consideration are significantly lower than their counterpart in Rostov region, which is $0.8 \%$ and $1.1 \%$ in the Russian Federation. Registered in the city's employment service as of 1 January 2018, 2612 unemployed citizens are registered, which is $16 \%$ less than in the same period last year. As of January 1, 2017, 8.9 thousand vacancies were registered in the city-wide data bank, $60.3 \%$ of which are proposals for blue-collar occupations. The average salary in the job bank is 18.6 thousand rubles.

Table 3. Level of registered unemployment, Rostov-on-Don (Developed by authors on the basis of Rostovstat, 2018)

\begin{tabular}{|l|l|l|l|l|l|l|}
\hline Years & 01.01 .2013 & 01.01 .2014 & 01.01 .2015 & 01.01 .2016 & 01.01 .2017 & 01.01 .2018 \\
\hline $\begin{array}{l}\text { Recognized by } \\
\text { the unemployed, } \\
\text { people }\end{array}$ & 2556 & 2220 & 2466 & 3345 & 3109 & 2612 \\
\hline $\begin{array}{l}\text { Level of } \\
\text { unemployment, } \\
\%\end{array}$ & 0.4 & 0.4 & 0.4 & 0.5 & 0.4 & 0.4 \\
\hline
\end{tabular}

The greatest need for labor was formed in the following activities: construction $(16.1 \%)$, in the wholesale and retail trade $(13.7 \%)$, in manufacturing $(12 \%)$, in the system of healthcare institutions and the provision of social services $(12,4 \%)$. It should be noted that $30.4 \%$ of vacancies came from the state and municipal sectors of the economy. In the course of the study, the position of Rostov-on-Don was determined in the ranking of Russian cities of over one million with respect to indicators of the social and labor sphere on the basis of the municipal statistics information system "Database of software and mathematical support of XX region "Indicators characterizing the state of the economy and social sphere of the municipality. Urban districts of XXX region. Urban district, urban district with intraurban division. XXX for 2013, 2014, 2015, 2016, 2017”.

According to the number of employees during 2013-2017. the city is in third place among the the Russian cities of over one million. During this period, the growth 
rates showed a steady increase in the range from $0.1 \%$ in 2013 to $3.5 \%$ in 2016 . The registered unemployment rate in Rostov-on-Don was one of the lowest among cities of over one million, except for Omsk. In terms of the average monthly salary of workers in Rostov-on-Don, it is in the middle of the list of cities of over one million ranked the seventh city.

According to data provided by the Institute of Urban Economics (Urbaneconomics, 2018), the top five of the ranking of capital cities of federal districts in terms of gross urban product (VUP) per capita are the capital cities of the regions of the North and the Far East, which have a raw material specialization. Moscow is in the sixth place, Saint Petersburg has not even entered the top ten positions and takes the $12^{\text {th }}$ place. The gap between the richest metropolitan city of Anadyr and the poorest metropolitan city of Makhachkala is 14 times, which indicates a high degree of economic differentiation of the capitals of Russian regions.

The larger the capital city is, the higher the value of the VUP per capita is. This suggests that agglomeration effects, in particular, the effect of "urbanization economies", manifest themselves in large metropolitan cities to a large extent. It is important that the intensity of the economies of scale in the cities in question is different - it depends on the structure of the economy and the efficiency in its individual spheres. For example, the economies of the cities of Novosibirsk and Chelyabinsk are comparable in terms of VUP per capita, although the latter is less populated by $25 \%$. Rostov-on-Don, being in the tenth place in terms of population, is fifth in terms of VUP per capita among capital cities. Consequently, the economies of scale in these cities work in different ways, which reflects the differences in the parameters of economic processes and in the possibilities of cities in terms of using their socio-economic potential.

\section{Results}

Based on the analysis of information materials, the competitive position of Rostovon-Don in the social and labor sphere was identified in the form of advantages, key problems and key trends that determine the possibilities and threats to the functioning and development of the social and labor sphere, as reflected in Table 4.

Table 4. Key trends, opportunities and hazards of functioning and developing the social and labor sphere of Rostov-on-Don

\begin{tabular}{|c|c|c|c|}
\hline SI.No. & Key trends & Key hazards & Key opportunities \\
\hline \multicolumn{4}{|c|}{ At the world level } \\
\hline 1 & $\begin{array}{l}\text { Growth of labor force } \\
\text { migration processes } \\
\text { due to globalization } \\
\text { and informatization of } \\
\text { the economy }\end{array}$ & $\begin{array}{l}\text { Influence of economic } \\
\text { crises on the ratio between } \\
\text { the demand and supply of } \\
\text { labor force. } \\
\text { Pressure of the labor market } \\
\text { of migrants representing }\end{array}$ & $\begin{array}{l}\text { Transformation of inter- } \\
\text { country migration into a } \\
\text { positive trend of social } \\
\text { development, including the } \\
\text { development of urban } \\
\text { agglomerations }\end{array}$ \\
\hline
\end{tabular}




\begin{tabular}{|c|c|c|c|}
\hline & & $\begin{array}{l}\text { mainly unskilled labor, } \\
\text { growth of shadow and } \\
\text { informal employment }\end{array}$ & \\
\hline 2 & $\begin{array}{l}\text { The reduction in the } \\
\text { number of people } \\
\text { employed in the } \\
\text { economy due to: } \\
-\quad \text { processes of } \\
\text { demographic aging of } \\
\text { the population; r } \\
-\quad \text { replacement of } \\
\text { manual labor with } \\
\text { robotized technologies }\end{array}$ & $\begin{array}{l}\text { Increased competition for } \\
\text { the possession of the most } \\
\text { valuable modern resource - } \\
\text { the human resource in the } \\
\text { context of globalization of } \\
\text { the world economy, } \\
\text { increasing the mobility of } \\
\text { the population and the } \\
\text { strong inertia of socio- } \\
\text { demographic processes }\end{array}$ & $\begin{array}{l}\text { The emergence of } \\
\text { qualitatively new jobs in the } \\
\text { city's labor market to meet } \\
\text { the needs of the digital } \\
\text { economy }\end{array}$ \\
\hline \multicolumn{4}{|c|}{ At the federal level } \\
\hline 1 & $\begin{array}{l}\text { Non-decreasing } \\
\text { unevenness of } \\
\text { regional development } \\
\text { of the Russian } \\
\text { Federation causing } \\
\text { significant differences } \\
\text { in income levels, } \\
\text { employment structure, } \\
\text { salaries, limiting the } \\
\text { migration of skilled } \\
\text { labor within the } \\
\text { country }\end{array}$ & $\begin{array}{l}\text { Lack of personnel for } \\
\text { innovative sectors of the } \\
\text { economy }\end{array}$ & $\begin{array}{l}\text { Elimination of barriers to } \\
\text { internal labor migration } \\
\text { based on the reduction of } \\
\text { territorial differences in the } \\
\text { level of income of the } \\
\text { population }\end{array}$ \\
\hline 2 & $\begin{array}{l}\text { The aging process of } \\
\text { the country's labor } \\
\text { force and the } \\
\text { reduction in the } \\
\text { working-age } \\
\text { population }\end{array}$ & $\begin{array}{l}\text { The growth of the pension } \\
\text { burden on workers due to } \\
\text { the decrease in the number } \\
\text { of people of working age } \\
\text { and the increase in the } \\
\text { number of citizens of } \\
\text { retirement age }\end{array}$ & $\begin{array}{l}\text { Ensuring the growth of real } \\
\text { wages of employees at } \\
\text { budgetary institutions of } \\
\text { education, health, culture } \\
\text { and social services, } \\
\text { providing additional } \\
\text { motivation for working } \\
\text { people of retirement age }\end{array}$ \\
\hline 3 & $\begin{array}{l}\text { Transformation of the } \\
\text { structure of demand } \\
\text { and supply of labor } \\
\text { due to the increasing } \\
\text { need for professional } \\
\text { skills of workers } \\
\text { associated with the } \\
\text { process of digitization } \\
\text { of the economy }\end{array}$ & $\begin{array}{l}\text { The insufficient quality of } \\
\text { the forecast on the number } \\
\text { and professional } \\
\text { qualification characteristics } \\
\text { of workers in the context of } \\
\text { accelerating scientific and } \\
\text { technological progress and } \\
\text { the transition to the } \\
\text { "digital" economy }\end{array}$ & $\begin{array}{l}\text { The rapprochement of the } \\
\text { vocational education system } \\
\text { with the needs of the } \\
\text { innovative economy in real } \\
\text { time }\end{array}$ \\
\hline
\end{tabular}




\begin{tabular}{|c|c|c|c|}
\hline 1 & $\begin{array}{l}\text { The imbalance of } \\
\text { supply and demand } \\
\text { for labor in the } \\
\text { territorial context, } \\
\text { concentration r of } \\
\text { supply and demand } \\
\text { for highly skilled } \\
\text { labor in the capital of } \\
\text { the region }\end{array}$ & $\begin{array}{l}\text { Structural imbalance in the } \\
\text { regional labor market. } \\
\text { The decrease in the number } \\
\text { of people of working age } \\
\text { and the increase in the } \\
\text { number of citizens of } \\
\text { retirement age. } \\
\text { Concentration of economic } \\
\text { activity in Rostov-on-Don } \\
\text { and forming a high intensity } \\
\text { of circular migration }\end{array}$ & $\begin{array}{l}\text { Flexible and balanced labor } \\
\text { market, guaranteeing } \\
\text { effective employment of } \\
\text { citizens and sustainable } \\
\text { economic development of } \\
\text { the city } \\
\text { Increased demand for highly } \\
\text { skilled labor based on } \\
\text { sustainable growth and } \\
\text { diversification of the } \\
\text { economy of Rostov-on-Don }\end{array}$ \\
\hline 2 & $\begin{array}{l}\text { Formation of large } \\
\text { educational clusters } \\
\text { designed to overcome } \\
\text { the shortage of } \\
\text { workers in the field of } \\
\text { IT-technologies and } \\
\text { the digital economy }\end{array}$ & $\begin{array}{l}\text { Incomplete compliance of } \\
\text { the vocational education } \\
\text { system with the demands of } \\
\text { the modern labor market } \\
\text { and the needs of the } \\
\text { "digital" economy }\end{array}$ & $\begin{array}{l}\text { Acceleration of the growth } \\
\text { rate of real incomes of the } \\
\text { population due to the } \\
\text { growth of labor } \\
\text { productivity, the increase in } \\
\text { the share of people } \\
\text { employed in high- } \\
\text { performance sectors, } \\
\text { including the production of } \\
\text { high-tech and innovative } \\
\text { products, the provision of } \\
\text { intelligent types of services, } \\
\text { as well as the penetration of } \\
\text { innovations into traditional } \\
\text { sectors of the economy } \\
\text { (trade, construction, } \\
\text { transport and energy } \\
\text { infrastructure) }\end{array}$ \\
\hline
\end{tabular}

\section{Discussion}

The target vector of the Strategy for the development of Rostov-on-Don in the social and labor sphere in terms of the implementation of the Presidential Decree dated May 2018 is raising the living standard of the population based on the formation of:

- a flexible and balanced labor market guaranteeing the effective employment of citizens and sustainable economic growth rates;

- spatial policy of urban development, taking into account the interests and needs of the human worker, as a determining factor of economic growth;

- consolidation of innovation, scientific and educational leadership of Rostov-onDon in the south of Russia by merging scientific, educational and innovation and industrial clusters.

It should be noted that municipal statistics in the course of introducing information technologies into the activities of municipalities received an impetus to the development. Nevertheless, the degree of awareness of local governments of the 
Russian Federation about the state and processes in the economic, social and other spheres of life is still insufficient. Serious systematic work is needed to solve the problems of municipal statistics and improve its information support, since the lack of information leads to inefficient solutions, which, as a result, affects the population's confidence in local authorities.

\section{References:}

Glebova, I.S., Khabibrakhmanova, R.R. 2012. Strategic management of socio-economic development of cities of over one million in modern Russia. Manual, Moscow.

GOV. 2018. Database of legal norms of government of the Russian Federation. Available online: http://www.static.government.ru.

Nivorozhkina, L.I. 2017. Statistical methods of data analysis. Textbook, Moscow.

Polyakova, I.A. 2018. Review of contemporary methods of information resources analysis. Scholarly Notes, Issue 21, RSUE publ., Rostov-on-Don.

Rostovstat. 2018. Rostov region in figures. Official Statistical collection, Rostov-on-Don

Urbaneconomics. 2018. Rating of capital cities of Russia. Available online: http://www.urbaneconomics.ru/centr-obshchestvennyh-svyazey/news/reytingstolichnyh-gorodov-rossii-ot-fonda-institut-ekonomiki.

Yusov, A.B. 2009. Social and labor sphere: trends for development, methods of monitoring and forecasting. Monograph, Moscow. 